\title{
Examination of the Composition and Microorganisms in the Oral Microflora with to Immunological Parameters Identification of Saliva
}

\author{
Abdulrazaq Mohammad SABAH ${ }^{1^{*}}$, Ikonnikova NATALIYA ${ }^{2}$ \\ ${ }^{1}$ International Sakarov Enviromental Institute of Belarusian State University, 32200, Minsk \\ *Corresponding Author Email : mohmmedaldraje4@ gmail.com ORCID: 0000-0003-1737-2874 \\ ${ }^{2}$ International Sakarov Enviromental Institute of Belarusian State University, 32200, Minsk \\ Email: i.nataliya@gmail.com - ORCID: 0000-0002-1733-1832
}

\section{$\underline{\text { Article Info: }}$}

DOI: $10.22399 /$ ijcesen.1011764

Received : 18 October 2021

Accepted : 04 November 2021

\section{$\underline{\text { Keywords }}$}

Mucosa

Micro flora

Oral cavity

\begin{abstract}
$\underline{\text { Abstract: }}$
The oral mucosa is a mucous membrane that connects the lips to the pharyngeal and gastrointestinal mucosa. Its particular properties enable it to function as a gatekeeper, regulating the impact of inhaled and ingested antigens, and the degrees of inflammation and immunological responses tolerated in a normal healthy mouth cavity. The objectives of this study are to: (1) quantification of the composition of the oral micro flora in individuals of 18-50 years old; (2) examination of the oral cavity microorganisms (culture-morphological and microscopic studies); and (3) determination the biochemical parameters (lysozyme concentration, active acidity level) of the oral fluid (saliva). Swabs from the oral cavity (within the cheeks) were used to inoculate agar media (MPA, Endo medium). Colonies (CFU) on the agar medium's surface were counted and converted to an area of the oral cavity $(4 \mathrm{~cm} 2)$. The oral fluid was collected in the morning, on an empty stomach, before brushing the teeth, into a sterile test tube with a tight-fitting cover. This was done by thoroughly cleaning the individual's mouth with a sterile $0.9 \% \mathrm{NaCl}$ solution. We used indicator strips of paper with $\mathrm{pH}$ ranges of 5.4-7.8, 0.2 steps. Oral fluid centrifuged (2000 rpm for $20 \mathrm{~min}$ ). The research revealed that those with periodontitis and caries had $\mathrm{pH}$ alterations in their saliva. The results showed that individuals with dental and periodontal issues had substantially lower levels of Lysozyme than healthy people. A severe decrease of nonspecific oral tissue resistance lowers oral fluid resistance to pathogens. Morever, Oral bacteria were all Amoxicillin resistant. Lactobacillus.
\end{abstract}

\section{Introduction}

The oral mucosa is defined as a mucous membrane that is continuous with the skin at the lips, and more importantly continuous with the pharyngeal mucosa and the gastrointestinal mucosa. While the oral mucosa shares many features with the skin and gastrointestinal mucosa it has many unique features that enable this sophisticated tissue to act as a gatekeeper controlling the effects of both inhaled and ingested antigens and the levels of inflammation and immune responses that are permitted in a normal healthy oral cavity. Most invaders access the body via external surfaces and the oral mucosa is exposed to a huge antigenic challenge in the form of ingested food and the microbes that make up the commensal oral flora [1 - 2].

It has been estimated that $>1000 \mathrm{~kg}$ of nutrients will pass through the adult gut per year and more than 700 different species colonise the oral cavity. Microbes, necrotic cells and hypoxia initiate inflammatory responses which, depending on the duration and severity, may result in clinical or pathological manifestations. The distinction of these tissues is important in understanding the differential immune responses that are possible within the oral cavity [3, 4]. The major lymphoid organs are the tonsils and adenoids, making up Waldeyer's ring and there are numerous lymph nodes draining the head and neck that contribute to the immune function of the oral immune system. Mammals have evolved a sophisticated innate and adaptive immune system that integrates this network of tissues, cells and effect of molecules and protects the body from disease by recognition of potential pathogens or diseased tissues $[5,6]$.

Saliva is uniquely adapted to the functions it needs to perform in the oral cavity. It continually bathes the 
hard and soft tissues to maintain the healthy tissues of the oral cavity, oropharynx, and larynx. Saliva is formed by three pairs of major salivary glands, namely parotid, submandibular, and sublingual, and hundreds of minor salivary glands, with some of the GCF being secreted from the gingival sulcus [7].

With the help of microorganisms, a person is able to perform functions that are not encoded by their own genome, for example, protection against invasive pathogens, extracting additional energy from food, synthesizing key molecules for the development of their own cells and tissues. Moreover, these functions of the microbiota are highly specialized and differ depending on the localization of microorganisms in the gastrointestinal tract and other loci of the human body. The main goal of the study is to the microflora of the human oral cavity, its participation in the formation of the body's immune system reactivity. However, the objectives of this study are to (1) characterize the qualitative and quantitative composition of the oral microflora from among the examined people aged $18-50$ years; (2) identify the microorganisms of the oral cavity (culturemorphological and microscopic studies); and (3) determine the biochemical parameters (lysozyme concentration, active acidity level) of the oral fluid (saliva) [8].

\section{Methodology}

To accomplish the study's objectives, 65 people of various ages (ranging from 18 to 50 years old) were examined, including students, teachers, laboratory assistants, and employees of Belarusian State University's International Sakharov Environmental Institute, as well as patients of the Slutsk district hospital who provided written informed consent for the collection of biological material. The study examined 65 individuals ranging in age from 18 to 50 years, including students, teachers, laboratory assistants, and employees of Belarusian State University's International Sakharov Environmental Institute, as well as patients of the Slutsk district hospital who provided written informed consent for the collection of biological material. A questionnaire survey was administered to the respondents to ascertain their susceptibility to colds or chronic illnesses, their bad habits (smoking), their practice of regular oral hygiene, and their lack of practice. Two groups were created on the basis of age: group 1 consisted of 37 individuals aged 18-25 years and group 2 consisted of 28 individuals aged 43-50 years. According to the survey's findings, 15 individuals were found to have different oral cavity illnesses. The remaining respondents did not have any oral cavity illnesses, as presented in Table 1.
Table 1: Group of people who took part in the study

\begin{tabular}{|l|l|l|}
\hline Category & Group 1 & Group 2 \\
\hline Age & $\begin{array}{l}18-25 \text { years } \\
(\mathrm{n}=37)\end{array}$ & $\begin{array}{l}43-50 \text { years } \\
(\mathrm{n}=28)\end{array}$ \\
\hline $\begin{array}{l}\text { Diseases of the } \\
\text { oral cavity }\end{array}$ & Present $(\mathrm{n}=15)$ & Absent $(\mathrm{n}=50)$ \\
\hline
\end{tabular}

The oral cavity (inside surface of the cheeks) was swabbed and inoculated onto agar media (MPA, Endo medium) using sterile cotton swabs. The quantitative count of microorganisms was accomplished by counting colonies (CFU) on the agar medium's surface and then converting to a specific unit of the oral cavity's area $\left(4 \mathrm{~cm}^{2}\right)$.

Saliva was collected in the morning, on an empty stomach, before to brushing the teeth, into a sterile test tube with a tight-fitting lid to determine the various parameters of the oral fluid. After thoroughly washing the mouth cavity with a sterile 0.9 percent $\mathrm{NaCl}$ solution, a 3-5 ml sample of saliva was obtained from the individual.

$\mathrm{pH}$ was determined using indicator strips of paper with a $\mathrm{pH}$ range of 5.4-7.8, with a step of 0.2 . Centrifuged the pre-collected oral fluid (2000 rpm for $20 \mathrm{~min}$ ). The $\mathrm{pH}$ of the supernatant was determined by dropping it onto indicator paper and calculating the $\mathrm{pH}$ value using a standard scale. To determine the lysozyme content, saliva from patients was collected in $1 \mathrm{ml}$ polyethylene tubes, diluted 1:1 with saline, and centrifuged at $1500 \mathrm{rpm}$ for 10 minutes. We analysed the supernatant. The ability of serum to act on a culture of micrococci grown on slanting agar is one way for determining lysozyme. A daily culture suspension in saline is made in accordance with an optical standard (10 U). The test serum is diluted with physiological solution tenfold, twentyfold, fortyfold, and eightfold, respectively. Each test tube is filled with an equal volume of microbial suspension. The tubes are shaken and then placed in a thermostat set to $37^{\circ} \mathrm{C}$ for 3 hours. The reaction is considered in relation to the serum's degree of clarity. The lysozyme titter is the final dilution at which the microbiological suspension is completely lysed. However, the measurements are made in calibrated test tubes to which $1 \mathrm{ml}$ of the studied lysozyme solution is added three times in parallel. $0.5 \mathrm{M}$ phosphate buffer is used as a control. To quantify lysozyme in unknown concentration solutions, a calibration curve is developed using enzyme concentrations of 2, 4, 6, $8 \mathrm{~g}$ in the sample. Use a standard solution of $200 \mathrm{~g} / \mathrm{ml}$ to dilute lysozyme. It is then used to make a stock solution of lysozyme at a concentration of $8 \mathrm{~g} / \mathrm{ml} .50 \mathrm{mg} / 100 \mathrm{ml}$ from dried lysozyme To construct the calibration curve, take ten tubes and arrange them as follows: (i) 1 and 2 control without lysozyme ( $1 \mathrm{ml}$ of water), (ii) 3 and 4 - $2 \mu \mathrm{g}$ of lysozyme $(0.25 \mathrm{ml}$ of lysozyme $+0.75 \mathrm{ml}$ of 
water), (iii) 5 and 6 - $4 \mu \mathrm{g}$ of lysozyme $(0.5 \mathrm{ml}$ of lysozyme $+0.5 \mathrm{ml}$ of water), (iv) 7 and $8-6 \mu \mathrm{g} \mathrm{L}$ of isozyme $(0.75 \mathrm{ml}$ of lysozyme $+0.25 \mathrm{ml}$ of water $)$, and (v) 9 and $10-8 \mu \mathrm{g}$ of lysozyme of $1 \mathrm{ml}$ of the original solution of lysozyme). Following the creation of all lysozyme solutions, $6 \mathrm{ml}$ of a suspension of micrococcus acetone powder is added to each test tube at a 30 second interval. Additionally, the hygienic state of the oral cavity was examined by inoculating the test material on the following nutrient media: meat-peptone agar (MPA), Endo's medium, Levin's medium, yolk-saline agar, Muller-medium, Hinton's and Czapek [9, 10].Inoculations should be incubated at $37^{\circ} \mathrm{C}$ for $18-24$ hours. The inoculations were permitted to incubate for up to 5 days in the absence of growth on blood agar, thioglycolic medium, or sugar broth. For 72 hours, inoculations in Sabouraud's medium were incubated simultaneously at $37^{\circ} \mathrm{C}$ and room temperature. The mean values, standard deviation $(\mathrm{M}+\mathrm{SE})$, median and spread of values, as well as correlation analysis, were determined using statistical methods during data processing. The Student's t-test was used to determine the significance of differences between indicator groups. Significant differences were defined as those with a $p 0.05$ value. When statistical analysis of the data was performed, a software package of 10.0 STATISTICA was used.

\section{Results and Discussions}

The hydrogen index of oral fluid (saliva) from healthy persons evaluated (table 2) was 6.970 .07 , which is within the range of normal values. Saliva $\mathrm{pH}$ changes were seen in a sample of patients with periodontal disease and tooth decay. The $\mathrm{pH}$ of the persons evaluated in this group was 5.03 0.2. The results indicated a statistically significant reduction in $\mathrm{pH}$ value when compared to a healthy control group and the norm. Fluctuations in saliva's hydrogen index can

Table 2: $p H$ value of oral fluid

\begin{tabular}{|l|l|l|l|}
\hline Indicator & $\begin{array}{l}\text { Group of } \\
\text { relatively } \\
\text { healthy people } \\
(\mathrm{n}=50)\end{array}$ & $\begin{array}{l}\text { Group of people } \\
\text { with caries and } \\
\text { periodontal } \\
\text { diseases }(\mathrm{n}=15)\end{array}$ & $\begin{array}{l}\text { Normal } \\
\mathrm{pH} \\
\text { value }\end{array}$ \\
\hline $\mathrm{pH}$ & $6,97 \pm 0,07 *$ & $5,03 \pm 0,2 *$ & $6,5-7,4$ \\
\hline
\end{tabular}

Take note that $*$ denotes differences with a p0,05 statistical significance.

result in a significant decrease in its mineralizing ability (acidification) or in its strengthening and the production of dental calculi. Acids created during microbial metabolism from carbohydrates that collect in the plaque due to the delayed flow of saliva through it can induce a drop in $\mathrm{pH}$. Thus, chronic sugar consumption can lower the $\mathrm{pH}$ of dental plaque to 5.0, promoting the growth of acid-producing bacteria such as lactobacilli and $\mathrm{S}$. mutans and predisposing to the formation of caries. Plaque $\mathrm{pH}$ decreases mostly as a result of sugar usage. According to the acquired findings, the concentration of lysozyme in the oral fluid of patients suffering from dental and periodontal illnesses is much lower than that of healthy individuals (Figure 1). The results indicated a severe deterioration of oral tissues' nonspecific resistance, which ultimately results in a deterioration of oral fluid's ability to resist the corrosive influence of pathogenic agents.

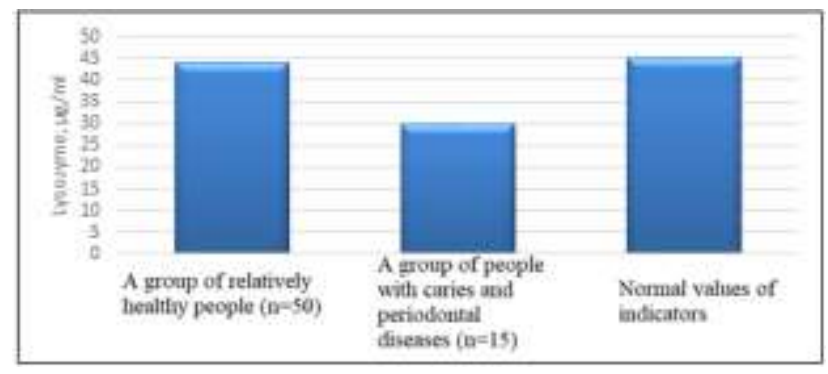

Figure 1: Lysozyme concentration $\mu \mathrm{g} / \mathrm{ml}$ in the examined individuals

It is well established that lysozyme is an enzyme involved in the formation of lysosomal cell structures. It is a critical component of non-specific protection related with the monocyte-macrophage system's function. The oral microbiota of the comparative groups was dominated by staphylococci and streptococci. Additionally, enterobacteria, veillonella, bacteria, bacteroids, actinomycetes, and Neisseria were Identified (table 4 and 5). Streptococcus genus representatives were the most commonly planted - accounting for $57 \%$ of all microorganisms sown in this biotope. Representatives of the staphylococci genus occupied $22 \%$, enterobacteria accounted for up to $15 \%$, occupied around $4 \%$, and Neisseria accounted for $2 \%$. Figure 2 illustrates the formation of several bacterial cultures in the form of distinct microorganism

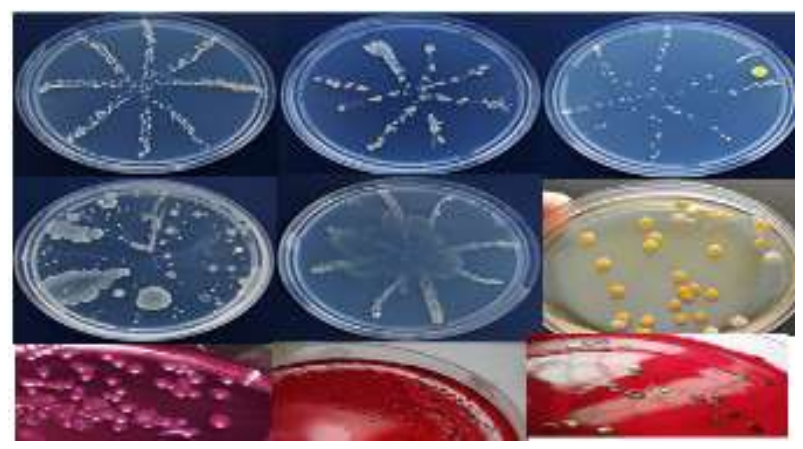

Figure 2 : examples of growth parameters of microbial colonies of the main representatives of the oral microflora on nutrient media

Table 3: Stabilizing (resident) flora 1. Aerobes and facultative anaerobes 


\begin{tabular}{|c|c|c|c|c|c|}
\hline \multicolumn{6}{|l|}{ Staphylococcus spp: } \\
\hline S. mutans & 39,8 & $2,3 \pm 0,28$ & 18,1 & $\begin{array}{c}\text { of } \\
5.3 \pm 1.01\end{array}$ & $\begin{array}{c}\text { at least 5- } \\
7\end{array}$ \\
\hline S. salivarius & 46,2 & of $1.7 \pm 0,12$ & 12,4 & $4,4 \pm 0,84$ & $\begin{array}{c}\text { at least 5- } \\
7\end{array}$ \\
\hline S. milleri & 21,2 & $1,5 \pm 0,31$ & 24,8 & $\begin{array}{c}\text { of } \\
6.2 \pm 0.93\end{array}$ & $\begin{array}{c}\text { at least 5- } \\
7\end{array}$ \\
\hline S. sanguis & 60,4 & $1,5 \pm 0,26$ & 58,2 & $3,5 \pm 0,70$ & $\begin{array}{c}\text { at least 5- } \\
7\end{array}$ \\
\hline Neisseria spp. & 28,4 & $4,2 \pm 0,54$ & 23,5 & $4,7 \pm 0,34$ & $\begin{array}{c}\text { at least 5- } \\
7\end{array}$ \\
\hline $\begin{array}{c}\text { Lactobacillus } \\
\text { spp. }\end{array}$ & 31,4 & $3,1 \pm 0,12$ & 29,6 & $\begin{array}{c}\text { of } \\
5.4 \pm 0.46\end{array}$ & $\begin{array}{l}\text { no more } \\
\text { than 3-4 }\end{array}$ \\
\hline $\begin{array}{c}\text { Enterococcus } \\
\text { spp. }\end{array}$ & 13,1 & $3,2 \pm 0,71$ & 56,2 & $3,4 \pm 0,67$ & $\begin{array}{l}\text { no more } \\
\text { than } 1-2\end{array}$ \\
\hline \begin{tabular}{|c|c|}
$\begin{array}{c}\text { Corinebacterum } \\
\text { spp. }\end{array}$ \\
\end{tabular} & 38,4 & of $2.6 \pm 0,94$ & 39,1 & $\begin{array}{c}\text { of } \\
5.4 \pm 0.36\end{array}$ & $3-4$ \\
\hline \multicolumn{6}{|c|}{ 2. Obligate anaerobes: } \\
\hline Veilonella spp. & 13.1 & $3.2 \pm 0.71$ & 39.1 & $5.4 \pm 0.36$ & $\begin{array}{l}\text { no more } \\
\text { than 3-4 }\end{array}$ \\
\hline Fusobacteria & 38.4 & $2.6 \pm 0.94$ & 56.2 & $3.4 \pm 0.67$ & $\begin{array}{l}\text { no more } \\
\text { than } 1-2\end{array}$ \\
\hline \multicolumn{6}{|c|}{$\begin{array}{l}\text { Non-permanent(transient) microbiota. Aerobes and facultative } \\
\text { anaerobes: }\end{array}$} \\
\hline \multicolumn{6}{|l|}{ Gram-negative rods: } \\
\hline S. aureus & 0 & \begin{tabular}{|c|} 
Not \\
determined
\end{tabular} & 35.2 & $4.7 \pm 0.52$ & 0 \\
\hline $\begin{array}{c}\text { S. epidermidis, S. } \\
\text { saprophvticus }\end{array}$ & 10.4 & $1.5 \pm 0.24$ & 44.4 & $4.7 \pm 0.42$ & $\begin{array}{l}\text { not more } \\
\text { than } 1-2\end{array}$ \\
\hline Escherichia coli & 2.8 & $1.7 \pm 0.16$ & 16.2 & $3.3 \pm 0.65$ & $\begin{array}{l}\text { not more } \\
\text { than } 1-2\end{array}$ \\
\hline Klebsiella & 1.1 & $1.5 \pm 0.12$ & 5.7 & $2.8 \pm 0.31$ & $\begin{array}{l}\text { not more } \\
\text { than } 1-2\end{array}$ \\
\hline \multicolumn{6}{|c|}{ Obligate anaerobes: Clostridia: } \\
\hline Clostridium tetani & 0 & Undetected & 39.1 & $5.1 \pm 0.26$ & 0 \\
\hline $\begin{array}{l}\text { Clostridium spp. } \\
\text { ramosum }\end{array}$ & 0 & $\begin{array}{c}\text { Not } \\
\text { determined }\end{array}$ & 24.8 & $3.2 \pm 0.93$ & 0 \\
\hline
\end{tabular}

colonies. The majority of the saliva flora is made up of facultative streptococci and veillonella, which enter mostly through the back of the tongue. Streptococcus salivarius is constantly vegetating on the tongue, where it is washed away by saliva, which also contains large concentrations of the bacteria. Neisseries are continually present in the oral cavity (and frequently in saliva), accounting for 3-5 percent of the bacteria produced (Table 3). Quantitative indications of microbial seeding from the oral cavity showed a considerable rise in titers of the following microorganisms: Lactobacillus spp., Staphylococcus aureus, Staphylococcus sepidermidis, Staphylococcus saprophyticus, and Staphylococcus mutans (Table 6). It is observed two characteristics of oral microbiocenosis: decreased colonization by representatives of the normal microbiota and

Table 4: Identification of qualitative and quantitative composition of carious-pathogenic oral microbiota Carious-pathogenic microbiota

\begin{tabular}{|c|c|c|c|c|}
\hline \multirow[b]{2}{*}{ Microorganisms } & \multirow{2}{*}{$\begin{array}{c}\text { detection } \\
\text { Rate, \% }\end{array}$} & \multicolumn{2}{|c|}{ Quantity in $1 \mathrm{ml}$} & \multirow[b]{2}{*}{$\begin{array}{c}\text { Standard } \\
\text { parameters }\end{array}$} \\
\hline & & $\begin{array}{c}1 \text { group } \\
18-25 \\
\text { years }(\mathrm{n}=\end{array}$ & \begin{tabular}{|c|}
2 group \\
$43-50$ \\
years $(n$
\end{tabular} & \\
\hline Klebsiella & 15 & $10 \pm 5$ & $40 \pm 9$ & 0 \\
\hline Escherichia coli & 2 & $7 \pm 3$ & $60 \pm 5$ & \pm \\
\hline Aerobacter & 3 & $9 \pm 6$ & $35 \pm 7$ & 0 \\
\hline Pseudomonas & \pm & Not & $9 \pm 3$ & 0 \\
\hline Proteus & \pm & $\begin{array}{c}\text { Not } \\
\text { determined }\end{array}$ & $16 \pm 6$ & 0 \\
\hline
\end{tabular}

Table 5: Identification of the qualitative and quantitative composition of paradontopathogenic oral microbiota Paradontopathogenic microbiota

\begin{tabular}{|c|c|c|c|c|}
\hline \multirow{2}{*}{ Microorganisms } & \multirow{2}{*}{$\begin{array}{c}\text { detectio } \\
\text { n Rate, } \\
\%\end{array}$} & \multicolumn{2}{|c|}{$\begin{array}{c}\text { Quantity in } 1 \\
\mathrm{ml}\end{array}$} & \multirow{2}{*}{$\begin{array}{c}\text { Standard } \\
\text { paramete } \\
\text { rs }\end{array}$} \\
\hline & & \begin{tabular}{|c|}
1 group, \\
$18-25$ \\
years, (n
\end{tabular} & \begin{tabular}{|c|}
2 \\
group \\
, $43-$
\end{tabular} & \\
\hline Porphyromonasgingiv & 15 & $25 \pm 4$ & $60 \pm 9$ & 0 \\
\hline Escherichia coli & 2 & $6 \pm 2$ & $28 \pm 5$ & \pm \\
\hline Aerobacter & 3 & $14 \pm 3$ & $35 \pm 7$ & 0 \\
\hline Pseudomonas & \pm & $\begin{array}{c}\text { Not } \\
\text { determine } \\
\mathrm{d}\end{array}$ & $15 \pm 3$ & 0 \\
\hline Proteus & \pm & $\begin{array}{c}\text { Not } \\
\text { determine } \\
\mathrm{d}\end{array}$ & $22 \pm 6$ & 0 \\
\hline
\end{tabular}

increased colonization by oral opportunistic microbiota with high adhesive qualities.The established method for determining the qualitative and quantitative composition of oral biocenoses expands the possibilities for early diagnosis, monitoring, and prognosis of the development of oral inflammatory illnesses.

\section{Conclusions}

The objectives of this study were to) quantify the composition of oral microflora in people aged 18-50; and examine oral cavity microorganisms (culturemorphological and microscopic studies); as well as assess oral fluid biochemical parameters (lysozyme concentration, active acidity level) (saliva). The study examined 65 individuals ranging in age from 18 to 50

Table 6 : Quantitative composition of oral microflora in the examined individuals $(M+m)$ Number of microorganisms in $1 \mathrm{ml}$ 


\begin{tabular}{|c|c|c|c|}
\hline $\begin{array}{l}\text { Type of } \\
\text { microflora }\end{array}$ & $\begin{array}{l}\text { Standard } \\
\text { indicators }\end{array}$ & $\begin{array}{l}1 \text { group , } \\
18-25 \\
\text { years, }(\mathrm{n} \\
=37)\end{array}$ & $\begin{array}{c}\text { group 2, } \\
43-50 \\
\text { years, } \\
(\mathrm{n}=28)\end{array}$ \\
\hline $\begin{array}{l}\text { Lactobacillus } \\
\text { spp. }\end{array}$ & $\begin{array}{l}\text { no more } \\
\text { than } 3-4\end{array}$ & $\begin{array}{c}\text { of } \\
3.01 \pm 0,12\end{array}$ & $\begin{array}{c}\uparrow 5,44 \pm 0,4 \\
6\end{array}$ \\
\hline $\begin{array}{c}\text { Staphylococc } \\
\text { us aureus }\end{array}$ & $\begin{array}{l}\text { no more } \\
\text { than 3-4 }\end{array}$ & $\begin{array}{c}\text { of } \\
2.54 \pm 0,08\end{array}$ & $\begin{array}{c}\uparrow \\
6,35 \pm 0,68\end{array}$ \\
\hline $\begin{array}{l}\text { Staphylococc } \\
\text { us } \\
\text { epidermidis, } \\
\text { saprophyticus }\end{array}$ & $\begin{array}{c}\text { more than } \\
3-4\end{array}$ & $\begin{array}{c}\text { of } \\
2.86 \pm 0,06\end{array}$ & $4,17 \pm 0,21$ \\
\hline $\begin{array}{l}\text { Staphylococc } \\
\text { us salivarius }\end{array}$ & $\begin{array}{c}\text { at least 5- } \\
7\end{array}$ & $\begin{array}{c}\text { of } \\
7.98 \pm 0,06\end{array}$ & $5,19 \pm 0,28$ \\
\hline $\begin{array}{c}\text { Staphylococc } \\
\text { us sanguis }\end{array}$ & $\begin{array}{l}\text { no more } \\
\text { than 5-7 }\end{array}$ & $\begin{array}{c}\text { of } \\
7.01 \pm 0,71\end{array}$ & $4,27 \pm 0,89$ \\
\hline $\begin{array}{l}\text { Staphylococc } \\
\text { us mutans }\end{array}$ & $\begin{array}{l}\text { no more } \\
\text { than 5-7 }\end{array}$ & $\begin{array}{c}\text { and } \\
3.21 \pm 0,12\end{array}$ & $\begin{array}{c}\uparrow \\
8,26 \pm 0,1\end{array}$ \\
\hline $\begin{array}{l}\text { Staphylococc } \\
\text { us } \\
\text { haemolyticus }\end{array}$ & $\begin{array}{c}\text { the } \\
\text { absence of }\end{array}$ & 0 & $\begin{array}{c}\text { to } \\
2.47 \pm 0,34\end{array}$ \\
\hline $\begin{array}{l}\text { Enterococusf } \\
\text { aecium }\end{array}$ & $\begin{array}{l}\text { no more } \\
\text { than } 1-2\end{array}$ & $\begin{array}{c}\text { of } \\
1.01 \pm 0,05\end{array}$ & $2,26 \pm 0,8$ \\
\hline Neisseria spp. & $\begin{array}{l}\text { no more } \\
\text { than 5-7 }\end{array}$ & $4.26 \pm 0.28$ & $5.93 \pm 0.25$ \\
\hline $\begin{array}{l}\text { Actinomyces } \\
\text { species }\end{array}$ & $\begin{array}{l}\text { no more } \\
\text { than } 2-3\end{array}$ & $2.17 \pm 0.06$ & $1.54 \pm 0.05$ \\
\hline
\end{tabular}

years, including students, teachers, laboratory assistants, and employees of Belarusian State University's International Sakharov Environmental Institute, as well as patients of the Slutsk district hospital who provided written informed consent for the collection of biological material. The results obtained from the analysis indicated that the A group of persons with periodontitis and caries had $\mathrm{pH}$ changes in their saliva. The $\mathrm{pH}$ of this group was 5.03 0. 2. The $\mathrm{pH}$ dropped significantly compared to the healthy group. The results revealed that the Lysozyme level in oral fluid is much lower in patients with dental and periodontal problems than in healthy persons. This suggests a severe loss of nonspecific oral tissue resistance, which necessarily reduces oral fluid resistance to pathogenic agents. Morover, The oral bacteria were all resistant to Amoxicillin. Carbenicillin-resistant Lactobacillus, Staphylococcus, Bifidobacterium, Escherichia, and Sarcina bacteria. Streptomycin, Doxycycline, and Tetracycline were all active.

\section{Author Statements:}

- The authors declare that they have equal right on this paper.

- The authors declare that they have no known competing financial interests or personal relationships that could have appeared to influence the work reported in this paper
- The authors declare that they have nobody or nocompany to acknowledge.

\section{References}

[1] Ebersole, J. L., Schuster, J. L., Stevens, J., Dawson, D., Kryscio, R. J., Lin, Y., \& Miller, C. S. (2013). Patterns of salivary analytes provide diagnostic capacity for distinguishing chronic adult periodontitis from health. Journal of clinical immunology, 33(1), 271279.

[2] Gursoy, U. K., Könönen, E., Pradhan-Palikhe, P., Tervahartiala, T., Pussinen, P. J., Suominen-Taipale, L., \& Sorsa, T. (2010). Salivary MMP-8, TIMP-1, and ICTP as markers of advanced periodontitis. Journal of clinical periodontology, 37(6), 487-493.

[3] Özcan, E., Saygun, N. I., Serdar, M. A., \& Kurt, N. (2015). Evaluation of the salivary levels of visfatin, chemerin, and progranulin in periodontal inflammation. Clinical oral investigations, 19(4), 921928.

[4] Tabari, Z. A., Azadmehr, A., Nohekhan, A., Naddafpour, N., \& Ghaedi, F. B. (2014). Salivary visfatin concentrations in patients with chronic periodontitis. Journal of periodontology, 85(8), 10811085.

[5] Kinney, J. S., Morelli, T., Braun, T., Ramseier, C. A., Herr, A. E., Sugai, J. V., \& Giannobile, W. V. (2011). Saliva/pathogen biomarker signatures and periodontal disease progression. Journal of dental research, 90(6), 752-758.

[6] Teles, R. P., Likhari, V., Socransky, S. S., \& Haffajee, A. D. (2009). Salivary cytokine levels in subjects with chronic periodontitis and in periodontally healthy individuals: a cross-sectional study. Journal of periodontal research, 44(3), 411-417., 1-13.

[7] Koh, D. S. Q., \& Koh, G. C. H. (2007). The use of salivary biomarkers in occupational and environmental medicine. Occupational and environmental medicine, 64(3), 202-210

[8] Gursoy, U. K., Könönen, E., Uitto, V. J., Pussinen, P. J., Hyvärinen, K., Suominen-Taipale, L., \& Knuuttila, M. (2009). Salivary interleukin- $1 \beta$ concentration and the presence of multiple pathogens in periodontitis. Journal of clinical periodontology, 36(11), 922-927.

[9] Tobón-Arroyave, S. I., Jaramillo-González, P. E., \& Isaza-Guzman, D. M. (2008). Correlation between salivary IL-1 $\beta$ levels and periodontal clinical status. Archives of oral biology, 53(4), 346-352.

[10] Mirrielees, J., Crofford, L. J., Lin, Y., Kryscio, R. J., Dawson III, D. R., Ebersole, J. L., \& Miller, C. S. (2010). Rheumatoid arthritis and salivary biomarkers of periodontal disease. Journal of clinical periodontology, 37(12), 1068-1074. 